\title{
The Songs of Innocence-Blake's Intuitive Flights into the Realm of the Absolute
}

\author{
Dr. B. Venkataramana
}

Asst. Professor in English

Sri Satya Sai Institute of Higher Learning

Muddenahalli Campus, Karnataka, India

venkataramanabalaga74@gmail.com

\begin{abstract}
Just like William Wordsworth who came a little later William Blake was known for an absolute sincerity, a mystic renunciation and a boldness of spirit. His originality and individuality, both of which were of a high order, came in the way of his public acceptance and acclaim. His drawings bear the stamp of a "characteristic and inimitable vision". His poetry is marked by the utmost subtlety of symbolism and the skill with which it is sustained is truly matchless. The philosophical framework of his poetry is no more than a series of "intuitive flights into the realm of the absolute, soaring with tranquil and imperious assurance". In Blake's view the world of children, which is not contaminated by experience, is almost heavenly. In fact childhood is like a compensation for the loss of Eden. In the poems of Blake, the divine that is described is Jesus Christ who, even like human children, was a child once and spoke of the merciful and compassionate heavenly father, God. Children are free from cares and conflicts and always in a state of happiness and harmony with the human society around them and nature.
\end{abstract}

Keywords: Mystic Renunciation, Inimitable Vision, Intuitive Flights, Heavenly Father, Harmony 
Just like William Wordsworth who came a little later William Blake was known for an absolute sincerity, a mystic renunciation and a boldness of spirit. Whatever, he did, he allowed himself to be ruled only by his instinct. That was how the peaks of his achievement were beyond the reach of other poets. His inspiration has a unique simplicity, purity and depth.

His originality and individuality, both of which were of a high order, came in the way of his public acceptance and acclaim. His drawings bear the stamp of a "characteristic and inimitable vision". His poetry is marked by the utmost subtlety of symbolism and the skill with which it is sustained is truly matchless. The philosophical framework of his poetry is no more than a series of "intuitive flights into the realm of the absolute, soaring with tranquil and imperious assurance".

The work of Blake can be classified under the following heads I. Lyrical poems including SONGS OF INNOCENCE and SONGS OF EXPERIENCE, II. Irregular rhyme less verse, III Rhythmic prose and IV Critical and descriptive prose. This paper then aims at bringing out the quintessence and lyrical intensity of poems in his SONGS OF INNOCENCE.

The lyrical poems of Blake constitute a realm of poetry, which is unequalled in many ways. There is in them an ineffable blend of spontaneity, creativity, and spiritual profundity. The dominant theme of these writings, however, is how the impassioned soul of a child feels and reacts. The essence of Romanticism is distilled in these poems, whether the subject is love and happiness, as in the SONGS OF INNOCENCE orgrief and rebellion as in SONGS OF EXPERIENCE. That which finds utterance in them is a real innocence, not what we imagine to be the innocence of a child, which cannot be expressed, but the achieved innocence of a reborn man. There is a complete renewal of the being, which finds a spontaneous symbolic expression in the innocence, simplicity, sharpness and purity of a child.

The essential features of Romanticism are present here-"the sense of wonder, the contemplation of nature through fresh eyes, an intimate sympathy with the varieties of 
existence most distant from the reach of our clear intelligence". There is a rare acuteness of perception and freshness of outlook. Everything that is perceived is bathed in a halo of mystery and beauty". In these poems of Blake English poetry does achieve a new glow of life and the dried-up spring of Elizabethan lyricism seem to well up again.

Edward Fitzgerald, in the course, employing the criteria sublimity says:

I take pleasure in reading things I don't wholly understand; just as the old women like sermons: I think it is of a piece with an admiration of all nature around us. I think there is a greater charm in the half meanings and glimpses of meaning that come in through Blake's wilder visions: though his difficulties arose from a very different source from Shakespeare's.

In SONGS OF INNOCENCE Blake is a "Child Angel", wearing a "brow of thought". He imagines himself to be a child and sometimes does become a child:

From addressing the child, the poet, by a transition not infrequent with him, passes out of himself into the child's person, showing a chameleon sympathy with childlike feelings. Can we not see the little three-year-old prattler stroking the white lamb, her feelings made articulate for her ?- Even more remarkable is the poem entitled The Lamb, sweet hymn of tender infantine sentiment appropriate to that perennial image of meekness; to which the fierce eloquence of The Tiger, in the Songs of Experience, is an antitype. In The Lamb, the poet again changes person to that of a child.

The SONGS OF INNOCENCE, John Middleton Murray says, are the creative uprush which followed Blake's perception of the infinite in all things. They are, he says, songs of "innocence" because this entry I..... to world of Spiritual Sensation is the entry of a reborn soul into a new world. By seeing the infinite in all things', one can feel sure, Blake meant the same thing as to see.

To see a World in a Grain of Sand

And a Heaven in a Wild Flower 
Hold Infinity in the palm of your hand

And Eternity in an hour

(Auguries of Innocence)

To, see the infinite in all things', thus, is to be aware by imagination or Spiritual Sensation' of things in their incommensurable individuality'. This is also the internal individuality. When Blake says that he who sees the infinite in all things sees God, he is only expressing the eternal and ultimate realization of the mystic.

On the title page of this volume, there is a symbolic design by the side of the year 1789 and the words "The Author and printer W. Blake. The title is printed in decorative words with the leaves and tender branches of a plant around them. Below the title, there is an apple plant and motherlike figure with two children in her lap reading a book.

In Blake's view the world of children, which is not contaminated by experience, is almost heavenly. In fact childhood is like a compensation for the loss of Eden. In the poems of Blake, the divine that is described is Jesus Christ who, even like human children, was a child once and spoke of the merciful and compassionate heavenly father, God. Children are free from cares and conflicts and always in a state of happiness and harmony with the human society around them and nature. It is this that constitutes of them in THE SONGS OF INNOCENCE the unity of God and Nature, childhood and innocence and joy and love.In the songs written on children and childhood and in the songs in which children figure, it is this oneness of child and God that suggested, with God being imagined as the infant Jesus .Nature is identified with the divine.

Further, Nature and lamb are identified with each other and in Blake's view the lamb is a metaphor of Jesus.

The images that recur in these poems are the hills and vales and their greenery the meadows and the grazing lambs, and its innocence that is all- pervasive. The adults that 
figure-fathers, mothers and nurses are those that feel happy at the happiness of the children, who sing and play and give expression to infectious joy.

The sunset and the end of day lead to the innocence of sleep, which is guarded by the angels.

Weeping is often referred to, but it is intense joy that's responsible for the tears though sometimes it is also a state of helplessness and a mood of pity. All doubts and fears are eliminated by the faith that the kingdom of God is going to be a reality in which the lion and the lamb will be together, with the lion acquiring a new glorious majesty and power by its goodness. The prophecy and the promise of the Old Testament that the meek will finally triumph will thus come true.

In this world of children, where innocence and purity prevail, it is God who is the source of SUCCOR and strength. This was Blake's vision of perfection in this world. Even like the Romantic poets that followed, Blake's discontinued reason and believed in the supremacy of the spontaneous impulse and compulsiveness and self-sufficing power of intuition.

Now let's see some of the songs including the introduction, there are nineteen of them. The last stanza of the introduction runs as follows.

And I made a rural pen,

And I stain'd the water clear,

And I wrote my happy songs

Every child may joy to hear

This makes the intention of the poet clear.

The third song The Lamb runs thus:

Little Lamb who made thee?

Dost thou know who made thee? 
Gave thee life \& bid thee feed.

By the stream \& o'er the mead;

Gave thee clothing of delight,

Softest clothing wooly bright;

Gave thee such a tender voice,

Making all the vales rejoice!

The poem deepens in its meaning when we come to the second stanza. The lamb and the speaker who is a child are both identified with Jesus, who is himself a little child. According to the European Christian tradition, Jesus is the Lamb of God. Lamb, as is well known is a symbol of meekness, gentleness and innocence.

He is called by thy name,

For he calls himself a Lamb:

He is meek \& he is mild,

He became a little child:

I a child \& thou a lamb,

We are called by his name.

While the lamb, the child, who is the speaker in the poem and God are individually referred to in the first stanza, they become one in the second stanza.

The next song "The little Black Boy" reveals the feelings of the little black boy in a moving manner, however, the feelings are free from an excess, and there is no trace of pathos. The boy who narrates to us the workings of his mind does not suffer from self-pity. He does not deny the white boy . On the other hand, he states that the skin, white or black, is but a cloud.Once it leaves, the black boy and the white boy will reach the company of the father in Heaven and play on His knees.

Ill shade him from the heat till he can bear, 
To lean in joy upon our fathers knee.

And then I'll stand and stroke his silver hair,

And be like him and he will then love me.

(The Little Black Boy)

While the Negro boy is reassured by his mother that his black skin is no more than a cloud and that at the appointed line it would leave him and he would enter into God's company 'The Chimney Sweeper' is able to get rid of the sooty layer on his white skin with a wash in a river on his way to Heaven where he too will reach the presence of the Father, who is God himself. Both the boys are thus sustained by their faith in God.

And by came an Angel who had a bright key,

And he opened the coffins \& set them all free;

Then down a green plain, leaping, laughing they run,

And wash in a river and shine in the Sun.

Then naked \& white, all their bags left behind,

They rise upon clouds, and sport in the wind.

And the Angel told Tom, if he'd be a good boy,

He'd have God for his father \& never want joy.

(The Chimney Sweeper) 


\section{References}

"Blake, William." Gale Contextual Encyclopedia of World Literature Vol. 1. 2009. 183-86. Galegroup.com. Web. 5 Nov. 2012.

"Blake, William - Introduction." Poetry Criticism. Ed. Jane Kelly Kosek. Vol. 12. Gale Cengage, 1995. 2006. 8 Oct, 2010

Lincoln A. Spiritual history: a reading of William Blake's Vala, or The four Zoas, Oxford University Press, 1995.

Bentley GE Jr: The Stranger From Paradise: A Biography of William Blake. New Haven, Conn, Yale University Press, 2001

William Blake, By Kathleen Raine, Longmans, Green \& Co., London 